\title{
Implementation of Inquiry Method Among of History Teachers In Secondary School
}

\author{
Siva Sankar R.Mahalingam, Ahmad Johari Sihes , Sivasangary Raveendran
}

\begin{abstract}
The purpose of this study is to investigate the implementation of the method of inquiry among history teachers in secondary schools in Pasir Gudang district. The main purpose of this study was to determine whether there is a significant relationship between the implementation of the method of teaching and teaching of History teachers especially the school location in Pasir Gudang district. Three aspects have been studied to address the research questions, namely, the level of knowledge, attitudes and skills of history teachers in implementing the method of inquiry in high school. The design used by the researcher was a quantitative research type of survey study involving 60 history teachers. Researchers used questionnaires as instruments and data were analyzed using content analysis techniques. The data obtained in this study were analyzed using Statistical Package for Social Science (SPSS) version 10.0. The findings show that the level of knowledge, attitudes and skills of history teachers are at a moderate level in the implementation of inquiry-based methods of teaching and learning. History educators are less confident in applying inquiry methods because they are less skilled in inquiry-based inquiry techniques. This study found several factors to impede the implementation of research methods such as time constraints, lack of teaching aids and student attitude. Some suggestions have been made to the history teachers to further enhance the implementation of inquiry-based methods in teaching and learning.
\end{abstract}

Index Terms: History Subject, Inquiry Method, History Teachers

\section{INTRODUCTION}

History Education is a core subject in the Curriculum Integrated High School (KBSM). In general, the course covers a variety of objectives and goals to stimulate the thinking of students through the process of learning as well as knowing the facts of historical development in Malaysia or around the world. Fatilah (2015), stated that this subject can stimulate critical thinking and analytical thinking and processes. History is a subject that can stimulate critical thinking and analytical thinking and processes. History is a story (narrative) about events that are thought to have occurred in the present (Mohd Mahzam, 2014). According to the Ministry of Education Malaysia (2016) the objective of KBSM is to develop and enhance critical and creative intellectual and creative thinking. Teachers should, therefore, use teaching and learning methods and techniques that can stimulate, stimulate and develop students' thinking skills to nurture and develop this intellectual capacity.

Revised Manuscript Received on October15, 2019

Siva Sankar R. Mahalingam, School of Education,Faculty of Social Sciences and Humanities UTM, Malaysia. (sivasankar53@ rocketmail.com)

Ahmad Johari Sihes, School of Education,Faculty of Social Sciences and Humanities UTM, Malaysia.(p-joha@utm.my)

Sivasangary Raveendran, School of Education,Faculty of Social Sciences and Humanities UTM, Malaysia.
Shaareney (2016),suggests that history is presented as a living force and can relate past events to current reality. In addition, every current or future problem can only be known through past events. Therefore, students need to be aware of this. According to Affan (2014),methods of teaching history by classroom teachers will influence the quality of history teaching in schools. The disciplinary structure of the history of the KBSM History includes an inquiry into history (Ministry of Education Malaysia, 2016). The use of inquiry findings emphasizes learning through experience. History is also said to be a discipline of knowledge that functions and develops to seek the truth of the past. It is clear that every time a teacher or historian is exposed to such questions, why, how, when and who. The students will then be guided by the teacher to ask questions at the beginning of the history study. As a result, to answer these questions, students will seek to find sources, evidence or information.

According to Abd Rahman (2016) to prove the social sciences, the method of inquiry was used. This method is applied as a teaching method in human subjects such as history. Because this method involves the process of finding conclusions from the questions formulated and the findings of the research, this method is also known as the investigative method. Real experiences can be gained by students when they are involved in the investigation of a phenomenon that occurs in their environment. Therefore, every student should be given the opportunity to enjoy the environment. Learning is more important when students study history in an inquiry-based way because students can investigate nature and find their own information. History is a fun subject when the method of inquiry is applied as students are actively involved in the process of investigating and seeking information. Teachers act more as facilitators of learning, asking questions and challenging student ideas and resources. In short, teachers no longer function as informers.

\section{LITERATURE REVIEW}

A good knowledge of history is not enough for a history teacher. Even as educators or educators, history teachers should be proficient and proficient in pedagogy and classroom practice (Anuar Ahmad, 2017). According to him, the lack of creative elements in the teaching of history has caused a student to become bored, ignorant and uninterested in history. This weakness is due to the weakness of the historical teaching methods practiced by historians who are unattractive and non-creative. 


\section{Implementation of Inquiry Method Among of History Teachers In Secondary School}

Students are also exposed to memorization methods (Ahmad Adam, 2013). Lazonder (2016) states that the implementation of inquiry methods in history subjects will greatly enhance students' ability to ask questions and efforts to find answers to teacher questions.

This method of inquiry is a method that can be used to prove the social sciences as well as a teaching method in historical subjects. Mohd Shafie (2012), also asserted that this method belongs to indirect learning consisting of exploration and discovery activities that are closely related to the process of obtaining information. Although there are many advantages to implementing the method of inquiry in historical subjects, there are many factors that make the method of inquiry less or less practiced in the classroom. Sivasankar (2018) emphasize that a teacher should provide students with the opportunity to collect, classify, observe, interview, review and make notes. The key to success in history subjects is to instill curiosity among students. Sandoval (2014) study suggest that educators should be aware of the purpose of teaching inquiry and ways of structuring learning experiences that can help students understand nature by engaging in investigative activities. Teachers' knowledge and experience in inquiry learning will have an impact on student understanding. The implementation of inquiry-based methods can develop manipulative capabilities and process information from a variety of sources such as academic, social and experiential (Zukas, 2015). According to Taylor (2012) implementation of inquiry also requires high level thinking skills and critical thinking to draw conclusions. To solve open-ended problems, students need high level thinking skills. Therefore, a teacher must have extensive knowledge and skills in implementing inquiry methods during the teaching and learning process. According to Anderson (2013), it is argued that low knowledge and skills in the implementation of inquiry methods are the cause of failure in the teaching and learning process.

Inadequate teacher preparation for inquiry activities causes teachers to fail when implementing teaching based on inquiry methods. According to Sandoval (2014) stated that teachers have low knowledge and skills in the implementation of inquiry. This is because, most teachers use teacher-centered teaching methods. The findings of Winnie, S.S.L and Mohammad Yusof Arshad (2014), show that teachers are negative about the implementation of inquiry methods. The result of this study is that after students give their answers, teachers are found to be evaluating, either giving praise, encouragement or guidance; and some even criticize or use justification of authority. Teachers also feel that this method of inquiry is not suitable for teaching because it takes time and cannot complete the syllabus. According to Bybee (2012) teachers' knowledge in the implementation of inquiry-based methods is very low. Teachers do not emphasize students 'existing knowledge, identify student misconceptions and restructure students' scientific ideas through hands-on activities. The attitude of a teacher is very important in handling the inquiry method in teaching. Positive attitudes will have a huge impact on student learning. Colburn (2010), in his study states that students are not only engaged in activities planned by teachers, but they are involved in unlimited activities. Teachers who demonstrate a positive attitude towards implementing the inquiry method can engage students in unlimited activities. A study conducted by Mohd Shafie (2012) found that teachers' positive attitudes toward inquiry-based methods can create teachers who are creative, innovative and develop a profession. Sivasankar (2018) mentions several key skills a teacher must develop such as questioning techniques, reinforcement techniques, guiding techniques and others as skills that teachers need to master. Awg Kasmurie et.al (2010) argues that History teachers can develop critical and creative thinking skills by using inquiry-based teaching methods. Pupils are able to provide amazing answers compared to the students' answers that are always exposed to traditional teaching methods. Teachers play an important role in producing first-generation students. Students become responsible when teachers use questioning skills (Barrow, 2015). So teachers only need to provide individual or group guidance. Inquiry handling skills will open the student's mind. According to Bybee (2012), teachers' skills in handling inquiry methods play an important role in teaching and learning. According to Nik Zarini \& Salmiza (2012), this method of inquiry findings will replace the teaching and learning that historians should practice.

\section{PURPOSE OF STUDY}

History is a subject that compulsory to pass by form five students. However, studies show students are not interested in History subjects and this results in a higher percentage of failures. Abdul Rahman (2016) states that inquiry is a method used to make students aware, aware, and aware of what they are already experiencing. Teaching and learning based on inquiry methods can provide opportunities for students to engage in intellectual processes. The use of inquiry methods has left teachers unmoved by the presentation of knowledge, data or information as usual. This is because, student involvement is very important in the use of discovery methods for teaching and learning sessions. Students will plan the learning process. So teachers act only as facilitators, mentors or mentors in the teaching and learning process. The use of inquiry-based methods in teaching and learning can open up opportunities for exploration, research, problem solving, conclusion and so on. Although the methods of inquiry have many advantages, History teachers still use traditional teaching. In general, the purpose of this study is to identify the level of knowledge of the history teachers of National Secondary School in Johor Bahru in the use of inquiry-based methods to achieve the purpose and goals of teaching and learning history based on the content of KSSM, the Secondary School Curriculum. This study also aims to explore and explore the application of inquiry-based methods in attitude-based history teaching. In addition, to study the level of teachers' skills in the use of inquiry methods during teaching and learning of historical subjects.

\section{METHOD}

This study is a quantitative study. The researcher uses survey method to test the research objective. In this study, the survey method is used to study the level of implementation of

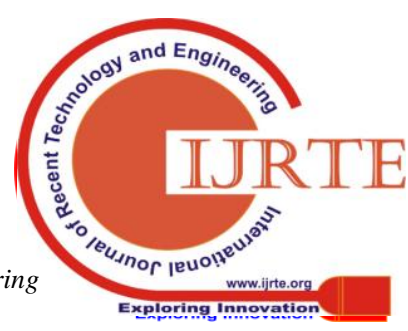


the discovery method in the teaching and learning of History subjects. The level of implementation is reflected in the extent to which teachers are equipped with the knowledge, attitudes and skills in applying inquiry-based methods in teaching and learning History in schools. The respondents of this study consisted of male teachers as well as female teachers. A total of 60 teachers from regular secondary schools located in the Pasir Gudang area were selected as the sample for this study. The respondents of this study were teachers involved in the teaching and learning process for History subjects. Such sampling will reduce the cost, energy and time of the research. Structured random sampling techniques used to facilitate cost-effective and time-consuming research and time constraints. The instruments used for this study were modified and divided into four sections, namely Section A, Part B, Part $\mathrm{C}$ and Part D. Part A contains demographic characteristics of the respondents to be studied. Part B, Part C and Part D are questionnaires aimed at examining the level of knowledge of teachers in the implementation of inquiry methods, teachers 'attitudes in implementing inquiry methods and teachers' skills in implementing inquiry methods.

\section{RESULTS AND DISCUSSION}

This section discusses the results of the study based on the research question. Respondents were asked about their knowledge, attitudes and skills in implementing the method of discovery in historical subjects.

a. What is the implementation of the method of inquiry among history teachers in a secondary school in Pasir Gudang district based on knowledge?

Knowledge of the implementation of inquiry-based methods is essential to the teaching and learning process. This is because learning objectives are achieved when teachers master the knowledge of inquiry-based methods. 60 history teachers were given questionnaires to find out the level of knowledge of the implementation of the discovery method.

\section{TABLE 1 : History Teacher Knowledge Score on Implementation of Inquiry Methods}

\begin{tabular}{|c|c|c|c|c|}
\hline Bil & Item Of Knowledge & Min & SP & Level \\
\hline 1 & $\begin{array}{l}\text { I can used inquiry method } \\
\text { with confidence. }\end{array}$ & 2.53 & .681 & Moderate \\
\hline 2 & $\begin{array}{l}\text { I was able to look for } \\
\text { opportunities to learn the } \\
\text { methods of inquiry discovery } \\
\text { to improve knowledge. }\end{array}$ & 2.63 & .490 & Moderate \\
\hline 3 & $\begin{array}{l}\text { I can design learning } \\
\text { activities that integrate the } \\
\text { implementation og inquiry } \\
\text { method during teaching } \\
\text { sessions. }\end{array}$ & 2.37 & .615 & Moderate \\
\hline 4 & $\begin{array}{l}\text { I have knowledge of using } \\
\text { inquiry methods for the } \\
\text { purpose of teaching and } \\
\text { learning History. }\end{array}$ & 2.27 & .640 & Low \\
\hline 5 & $\begin{array}{l}\text { I can order the importance of } \\
\text { the content in using the } \\
\text { inquiry method. }\end{array}$ & 2.80 & .407 & Moderate \\
\hline 6 & $\begin{array}{l}\text { Knowledge of the method of } \\
\text { inquiryaroused my interest to } \\
\text { used in History subject. }\end{array}$ & 2.53 & .730 & Moderate \\
\hline 7 & $\begin{array}{l}\text { I can use inquiry methods in } \\
\text { teaching other subjects. }\end{array}$ & 2.47 & .730 & Moderate \\
\hline
\end{tabular}

Based on Table 1 above, the mean score of the overall history of teacher knowledge on the implementation of teaching methods in teaching and learning is 2.51 . This mean score indicates that respondents who teach history subjects have a modest knowledge of the use of inquiry methods in the teaching and learning process. Table 1 shows that $63.3 \%$ of respondents were unsure about the implementation of the inquiry method. While $36.7 \%$ of respondents were not confident in implementing the inquiry method in the teaching and learning process of history. A total of 22 out of 60 respondents were unable to look for opportunities to learn in-depth methods to improve their knowledge. Only $43.3 \%$ of respondents were able to design and develop learning activities that could integrate the implementation of inquiry methods during the teaching session. A total of 38 respondents had no knowledge of the use of inquiry methods for the purpose of teaching and learning history. This explains that inadequate inquiry knowledge makes history teachers incapable of implementing teaching instruction. In addition, $33.3 \%$ of respondents indicated that knowledge of the method of inquiry did not arouse interest in using it in History subjects. About $40 \%$ of the respondents were unable to use the inquiry method in a variety of different subjects. This is particularly troubling because most history teachers have a modest knowledge of the implementation of inquiry methods. Overall, the findings show that teachers of history are aware of the implementation of inquiry methods at a moderate level and this has reduced the confidence of history teachers to use inquiry methods in the teaching and learning process.

b. What is the implementation of the inquiry method among history teachers at a secondary school in Pasir Gudang district based on their attitude?

\section{TABLE 2: History Teachers' Attitude Scores on Implementation of Inquiry Methods}

\begin{tabular}{|l|l|l|l|l|}
\hline Bil & \multicolumn{1}{|c|}{ Item Of Attitude } & Min & SP & Level \\
\hline 1 & $\begin{array}{l}\text { I enjoy learning how to use } \\
\text { inquiry methods in History } \\
\text { subject. }\end{array}$ & 3.03 & .414 & Moderate \\
\hline 2 & $\begin{array}{l}\text { The course of study } \\
\text { menthods can help the } \\
\text { teaching process. }\end{array}$ & 2.93 & .450 & Moderate \\
\hline 3 & $\begin{array}{l}\text { I always work with other } \\
\text { teachers in the } \\
\text { implementation of the } \\
\text { inquiry method. }\end{array}$ & 2.70 & .466 & Moderate \\
\hline 4 & $\begin{array}{l}\text { I feel that implementing the } \\
\text { inquiry method in the } \\
\text { teaching process takes a lot } \\
\text { of planning time. }\end{array}$ & 3.77 & .774 & High \\
\hline 5 & $\begin{array}{l}\text { Colleagues deliberately raise } \\
\text { trivial issues related to the } \\
\text { implementation of the } \\
\text { inquiry method in History } \\
\text { subject. }\end{array}$ & 3.63 & .809 & Moderate \\
\hline 6 & $\begin{array}{l}\text { Idiligently use the method of } \\
\text { inquiry in History subject } \\
\text { after taking the course of } \\
\text { inquiry method. }\end{array}$ & 2.50 & .777 & Moderate \\
\hline
\end{tabular}




\begin{tabular}{|l|l|l|l|l|}
\hline 7 & $\begin{array}{l}\text { I collaborated with friends to } \\
\text { share ideas using inquiry } \\
\text { methods in History subject. }\end{array}$ & 2.87 & .629 & Moderate \\
\hline 8 & $\begin{array}{l}\text { I look forward to new } \\
\text { challenges related to the } \\
\text { implementation of the } \\
\text { inquiry method. }\end{array}$ & 2.93 & .365 & Moderate \\
\hline
\end{tabular}

According to Table 2, the implementation of the survey method among history teachers based on the overall attitude is at a moderate level of 3.045. Most of the history teachers 'attitudes towards implementing inquiry methods in the teaching and learning process are at a moderate level and this will reduce students' thinking ability. According to Table 4, the findings show that $90 \%$ of 54 history teachers were not as comfortable learning how to use inquiry methods. This is because, the exposure given is very low and knowledgeable in the teaching of inquiry. For item 2, 56 respondents stated that the course methods introduced to them did not improve their teaching style and improved their ability to learn and think. This item explains that school administrators are less likely to practice professional development programs related to teaching and learning. $70 \%$ of respondents did not agree to cooperate with other teachers in implementing the inquiry method. This is because, 34 respondents said that the implementation of the inquiry method took a long time to plan. In addition, teachers are of the view that taking a long time can be a problem in completing history lessons. In addition, 24 respondents were not diligent in applying the method of inquiry in history subjects after taking the course of inquiry method. About $30 \%$ of respondents did not enjoy working with friends in sharing ideas for designing lessons that used inquiry methods in History subjects. Although respondents had a moderate attitude, $90 \%$ of respondents were prepared to face new challenges related to the implementation of the inquiry method.

c. What is the implementation of the inquiry method among history teachers in a high school in Pasir Gudang district based on their skills?

\section{TABLE 3: History Teachers Skills Scores on Implementation of Inquiry Methods}

\begin{tabular}{|l|l|l|l|l|}
\hline Bil & \multicolumn{1}{|c|}{ Item Of Skills } & Min & SP & Level \\
\hline 1 & $\begin{array}{l}\text { Skilled in the method } \\
\text { of inquiry in the } \\
\text { planning of History } \\
\text { subjects. }\end{array}$ & 2.97 & .556 & Moderate \\
\hline 2 & $\begin{array}{l}\text { Able to apply values } \\
\text { while using inquiry } \\
\text { method. }\end{array}$ & 3.23 & .430 & Moderate \\
\hline 3 & $\begin{array}{l}\text { Produce teaching aids } \\
\text { that include unquiry } \\
\text { methods in teaching of } \\
\text { History. }\end{array}$ & 2.53 & .571 & Moderate \\
\hline 4 & $\begin{array}{l}\text { Create active } \\
\text { interactions with } \\
\text { students while using } \\
\text { inquiry methods. }\end{array}$ & 2.50 & .777 & Moderate \\
\hline
\end{tabular}

Based on Table 3 above, the level of historical teachers' skills in the implementation of inquiry methods in the teaching and learning process. The overall mean squared for the skill level was moderate to the mean of 2.74. This means that the respondents have the basic skills to use the inquiry method during the historical teaching and learning process. According to Table 3 , only $13.3 \%$ of respondents used the method of inquiry in the planning of history subjects. $23.3 \%$ of which is only 14 respondents who are proficient in applying pure values when using inquiry methods in the teaching of history. A total of $56.7 \%$ of respondents were skilled in producing teaching aids that included inquiry methods in teaching history. Finally, $33.33 \%$ of respondents were not skilled in actively engaging with students while using inquiry methods in the process of teaching and learning history.

\section{CONCLUSION}

This study has generally demonstrated the level of implementation of the inquiry method in all aspects of the study which includes the knowledge, attitude and skills of the history teachers at the moderate level. However, history teachers still use traditional teaching because it is easy to master and can help students understand the theory (Kazempour, 2014). History teachers also do not understand how to use inquiry methods and this causes teachers to be unsure about using inquiry methods. Ortlieb (2013) argues that transfer of teacher knowledge to students is closely related to teacher experience. Time constraints also prevent teachers from choosing the method of inquiry because it takes time. The kindergarten teachers get information from history teachers who specialize in the implementation of inquiry methods. With this, time constraints can be overcome. History teachers also need to be aware of the benefits and importance of implementing inquiry methods in history subjects. Inquiry methods can actively increase student engagement and foster interest in learning history. Therefore, the Curriculum Development Division, educators in higher education institutions are expected to provide exposure through intensive courses and detailed teaching modules based on inclusive teaching as a guide for teachers (Winnie, S.S.L \& Mohammad Yusof Arshad, 2014).

\section{ACKNOWLEDGMENT}

The author would like to thank University Teknologi Malaysia for their support in making the project possible. This paper ostensibly supported by supervisor and co-authors.

\section{REFERENCES}

1. Abdul Rahman Hj Ismail7 Azmi Ariffin.(2016). Sejarah Kenegaraan dan Politik. Kuala Lumpur. Dewan Bahasa dan Pustaka.

2. Affan Budi Sentosa. (2014). Pengaruh Penerapan Teknik Pembelajaran Brainstorming Terhadap Hasil Belajar Siswa Dalam Mata Pelajaran Sejarah Pada Siswa Kelas XI IPS. Indonesian Jurnal Of History Education.3(2), 7 - 11

3. Ahmat Adam. 2013. Pendidikan Sejarah di Malaysia dewasa ini Sejauh manakah ia relevan kepada pembinaan nasion?. Seminar Kebangsaan Pendidikan dan Geografi. KotaKinabalu: Sekolah Pendidikan dan Pembangunan Sosial, Universiti Malaysia Sabah.

4. Anderson, R. (2013). The research on teaching as inquiry. Paper presented for the Center for Science, Mathematics and Engineering Education. National Research Council, Washington D.C.

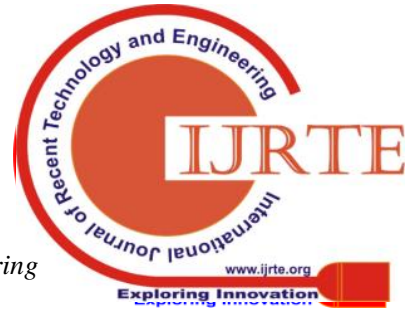


5. Anuar Ahmad. (2017). Tahap Keupayaan Pengajaran Guru Sejarah dan Hubungannya dengan Pencapaian Murid di Sekolah Berprestasi Rendah.Jurnal Pendidikan Malaysia 34(1)(2017): 53 - 66.

6. Awg Kasmurie Awg Kitot et al. (2010). The Effectiveness of Inquiry Teaching in Enhancing Students'Critical Thinking, Internationa Conference on Learner Diversity 2010 Procedia Social and Behavioral Sciences 7(C) 264- 273.

7. Barrow, L.H. 2015. Facilitating designs : For inquiry with the foue-question strategy. Science activities : Classroom projects and curriculum ideas, 45(1), 9-11. http://web.ebscohost.com.pdf [12 September 2008].

8. Bybee, R., Taylor J., Gardner A., Scotter, P., Powell, J., Westbrook, A., \& Landes, N., (2012). The BSCS 5E Instructional Model: Origins, Effectives, and Applications.Executive Summary, BSCS, Colorado Springs, CO.

9. Colburn, A. 2010. Consrtuctivism: Science education's "grand unifying theory". The Clearing House, 74(1), 9012.

10. Fathilah Akmal. (2015).Kemahiran Kerja Kursus Pentaksiran Tiga Sejarah Dalam Kalangan Pelajar Pelbagai Etnik.Proceeding of the 7th International Seminar On Resional Education. November 5-7, Vol 1.

11. Kementerian Pendidikan Malaysia. 2016. Dokumen Standard Sekolah Menengah: Sejarah. Kuala Lumpur: Dewan Bahasa dan Pustaka.

12. Kazempour, M. (2014). Impact of inquiry-based professional development on core conceptions and teaching practices: A case study. Science Educator, 18(2), 56-68.

13. Lazonder, A. W., \& Harmsen, R. (2016). Meta-Analysis of Inquiry-Based Learning: Effects of Guidance. Review of Educational Research, (1962), 1-38.

14. Mohd.Mahzam Awang.(2014). Penggunaan Peta Minda Oleh Pelajar Pintas Cerdas Dalam Pembelajaran Sejarah. No 2. Vol 39

15. Mohd Shafie b.Rosli, Baharuddin Aris \& Noraffandy Yahaya. 2012. Pembanguna Persekitaran Pembelajaran Inkuiri untuk Pendidikan Tertier dan Pengujian Keberkenanya. Jurnal Teknologi Pendidikan Malaysia 2(1): 23-35.

16. National Research Council. 2000. Inquiry and The National Science Education Standars: A Guide for Teaching and learning. Wahington, DC: National Academy Press. Tersedia http://books.nap.edu/html/inquiryaddendum/notice.html $\left[\begin{array}{ll}12 & \text { Julai }\end{array}\right.$ 2015].

17. Nik Zarini Nik Kar \& Salmiza Saleh. 2012. Kesan Pendekatan Inkuiri Penemuan Terhadap Pencapaian Pelajar Dalam Mata Pelajaran Kimia. Asia Pasific Journal of Educators and Education 27: 159-174.

18. Norakma Mohd Dauk. (2015). Pembelajaran Berteraskan Kemahiran Berfikir Aras Tinggi (KBAT) Di Dalam Pengajaran Dan Pembelajaran Mata Pelajaran Sejarah. Proceeding of the 7th International Seminar On Resional Education. November 5-7, Vol 1.

19. Ortlieb, E. T., \& Lu, L. (2013). Improving teacher education through inquiry-based learning. International Education Studies, 4(3), 41-46. doi: 10.5539/ies.v4n3p41

20. Sandoval, W. A., \& Reiser, B. J.(2014). Explanation-driven inquiry: Integrating conceptual and epistemic scaffolds for scientific inquiry. Science Education, 88, 342-375.

21. Shaareny Saravanan.(2016).Penggunaan Roda Masa Dalam Meningkatkan Kemahiran Menyusun Fakta Sejarah Mengikut Kronologi Dalam Kalangan Murid Tahap 4.International Seminar On Generating Knowledge Through Research, UUM-UMSIDA 25-27 October 2016.

22. Siva sankar Mahalingam. (2018). Implementation of Historical Thinking Skills in teaching History subject in the high schools. University Technology Malaysia.ISBN 978-967-0194-68-4.

23. Smith, L.K. 2005. The Impact of Early Life History on Teachers' Behals: In-School and Out-Of-School Experiences as Learners and Knowers of Science. Teachers and Teaching: Theory and Practice 11:5-36..

24. Taylor,T., Fahey, C., Kriewaldt, J. \& Boon, D. (2012). Place and Time: Explorations in teaching Geography and History. Pearson, Australia.

25. Winnie, S.S.L dan Mohammad Yusof Arshad. 2014. Corak Amalan Pengajaran Inkuiri Berdasarkan Interaksi Verbal Guru Kimia. Jurnal Kurikulum \& Pengajaran Asia Pasifik 2: 1-10.

26. Zukas, A. (2015). Active learning, world history, and the Internet:Creating knowledge in the classroom. International Journal of Social Education, 15(1), 62-79.

\section{AUTHORS PROFILE}

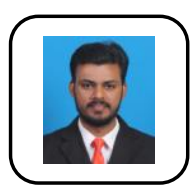

The first author's name is Siva Sankar A / L R. Mahalingam. The author has made a bachelor's degree in malaya university in 2008-2011. In 2015, the writer of my studies to the master's degree in education at the national university of malaysia. The author has written as many as 6 articles and has been published from 2015 until now. The author also won several awards such as a 3-minute presentation of thesis, poster presentation and national level innovation competition. Now the writer is doing PHD in malaysia technology university.irst author's name is Siva Sankar A / L R. Mahalingam. The author has made a bachelor's degree in arts at Malaya University in 2008-2011. In 2015, the author continue further studies to the master's degree in education at the National University of Malaysia. The author has written as many as 6 articles and has been published since 2015 until now. The author also won several awards such as a 3-minute presentation of thesis, poster presentation and national level innovation competition. Now the writer is doing PHD in University Technology of Malaysia.

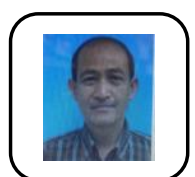

The second author's name is Professor Madya Dr Ahmad Johari Bin Sihes. The author working at Department of Educational Foundation and Social Science at Technology University Malaysia. In 1986 the writer received a bachelor's degree in chemistry at the University of Minnesota at Duluth USA. In 1988 the writer received masters degree in Curriculum Construction at the same university. In 2009 the authors graduated PHD at Universiti Teknologi Malaysia in the field of Curriculum and Instruction. The author has written as many articles and has been published .The author received award and several honors such as Science education award, excellent government service sward (MARA), excellence service award, best paper in national student development conference 2013, excellent residential college principal award and excellence service award 2016.

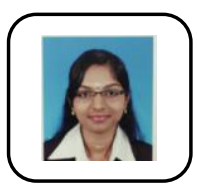

The third author's name is Sivasangary A/P Raveendran. The author has made a bachelor's degree in Temenggong Ibrahim Teacher Training College in 2009-2013. In 2016, the writer of my studies to the master's degree in education at the Technology University of Malaysia. Now the author working as a Mathematics teacher at SJK (T) Kangkar Pulai. The author also won several awards in international level innovation competition. 